\title{
Short Term Impact of Air Pollution on Asthma Admission in Ulaanbaatar
}

\author{
Altangerel Enkhjargal ${ }^{*}$, Otgonbyamba Oyun-Erdene2, Badrakh Burmaajav³, \\ Sambuu Tsegmed ${ }^{2}$, Batbaatar Suvd ${ }^{2}$, Byambagar Norolkhoosuren ${ }^{4}$, Dorj Unurbat ${ }^{5}$, \\ Jadamba Batbayar5, Davaakhuu Narantuya², Palam Enkhtuya² \\ ${ }^{1}$ Academy of Medical Professionals, Ulaanbaatar, Mongolia \\ ${ }^{2}$ National Center for Public Health, Ulaanbaatar, Mongolia \\ ${ }^{3}$ Ach Medical University, Ulaanbaatar, Mongolia \\ ${ }^{4}$ Department of Health Development, Ulaanbaatar, Mongolia \\ ${ }^{5}$ National Agency of Environmental Monitoring, Ulaanbaatar, Mongolia \\ Email: ^ajargal8@gmail.com
}

How to cite this paper: Enkhjargal, A., Oyun-Erdene, O., Burmaajav, B., Tsegmed, S., Suvd, B., Norolkhoosuren, B., Unurbat, D., Batbayar, J., Narantuya, D. and Enkhtuya, P. (2020) Short Term Impact of Air Pollution on Asthma Admission in Ulaanbaatar. Occupational Diseases and Environmental Medicine, 8, 64-78.

https://doi.org/10.4236/odem.2020.82005

Received: January 8, 2020

Accepted: April 12, 2020

Published: April 15, 2020

Copyright $\odot 2020$ by author(s) and Scientific Research Publishing Inc. This work is licensed under the Creative Commons Attribution International License (CC BY 4.0).

http://creativecommons.org/licenses/by/4.0/ (c) (i) Open Access

\begin{abstract}
Background: Asthma is a heterogeneous disease, usually characterized by chronic airway inflammation. The air quality is influenced by locations of the air pollution sources, their performance capacity, the technology used, the composition of waste generated and geographical and climate conditions. In this study, a time-series analysis was conducted to estimate the association of short-term exposure to ambient air pollutants and hospitalization due to asthma in Ulaanbaatar. Objectives: We estimate the short-term associations between daily changes in ambient air pollutants and daily asthma in Ulaanbaatar, Mongolia. Methods: This is a time-series cross over study. All asthma hospital admission and air pollution data of 2008-2017 was used for this assessment. Data analyzed by using the program STATA-12. For testing the differences of the results were used appropriate non-parametric tests. Result: The daily mean of sulfur dioxide concentration was $35.22 \mathrm{mg} / \mathrm{m}^{3}$ in the cold season, which was 7.57 times higher than the mean of the hot season. The mean annual PM 10 concentration was $182.73 \mu \mathrm{g} / \mathrm{m}^{3}$. Most of the cases of asthma were among women, aged between 5 - 64 years old, registered during winter and spring. 3.8 people admitted to the hospital mostly on weekdays. In all Lag of $\mathrm{SO}_{2}$, in Lag of $\mathrm{NO}_{2}$, in all Lag of PM 10, in PM 2.5 and in all Lag except for Lag 2 of CO, Lag 0 - 2 of $\mathrm{O}_{3}$ the incidence is likely to increase by $0.3 \%-6.1 \%$ per 10 units of pollutants. Conclusion: The air pollution especially PM 10, PM 2.5 , and $\mathrm{CO}$ are the most harmful air pollutants to asthma in Ulaanbaatar. The correlation mainly between asthma admission cases with meteorological parameters is because of the cold winter condition.
\end{abstract}




\section{Keywords}

Air Pollution, Asthma, Time-Series Cross Over, Lag, Ulaanbaatar Air Pollution

\section{Introduction}

Asthma is a heterogeneous disease, usually characterized by chronic airway inflammation. It is defined by the history of the respiratory symptoms such as wheeze, shortage of breath, chest tightness and cough that vary over time and in intensity, together with variable expiratory airflow limitation. Also, asthma is a common, chronic respiratory disease affecting $1 \%-18 \%$ of the population in different countries [1].

Numerous studies were conducted in different regions of worldwide to define the relationship between air pollutants and asthma. According to Zheng X-Y et al., short-term exposure to air pollutants confers an increased risk of asthma-related emergency room visits and hospital admissions and it needs to be interpreted cautiously since longer lags are essential in time-series studies to better determine the effects of outdoor air pollution on asthma outcomes [2].

Air pollution has been increasing intensively during last decade in big cities of Mongolia especially in Ulaanbaatar due to urbanization, poor urban plan, migration from rural areas to urban areas, poverty, unemployment, economic crises, exercise with unclean technology mainly coal for heating and cooking, raise of number of motor vehicle and other air pollution sources; as result of this phenomena population health has been worsening. Especially in wintertime $\mathrm{SO}_{2}$, PM 10 and PM 2.5 concentrations are very high in ambient air because of raw coal usage in ger area around big cities such as Ulaanbaatar. Therefore, Ulaanbaatar is considered as the focus of air pollution.

The air quality is influenced by locations of the air pollution sources, their performance capacity, a technology used, the composition of waste generated and geographical and climate conditions. Almost a third of the population of Mongolia is children and 69 percent of the population lived in urban areas. As a consequence of drastic urban migration, Ulaanbaatar is facing significant environmental and developmental challenges since the 1990s [3]. In 2010, the average daily concentration of nitrogen in the air in Ulaanbaatar has more than doubled since 2007 and the average daily concentration of sulfur dioxide has almost trebled [4].

In this study, a time-series analysis was conducted to estimate the association of short-term exposure to ambient air pollutants and hospitalization due to asthma in Ulaanbaatar with the data from 2008-2017.

\section{Materials and Methods}

This is a time-series cross over study. All asthma hospital admission and air pollution data of 2008-2017 was used for this assessment. 


\subsection{Location of the Study}

Ulaanbaatar, Mongolia is the coldest capital city in the world, with average winter low temperatures of $-20^{\circ}$ Celsius. Many families there live in gers, traditional Mongolian dwellings consisting of a wooden frame beneath several layers of wool felt. In the ger districts of Ulaanbaatar, cooking and heating energy is provided through indoor coal combustion in metal stoves with chimneys, and in wintertime, such stoves may be in use both day and night. The stationary and mobile sources of air pollution have polluted the neighboring areas and also the smokes from the ger areas surrounding the city have moved from uptown to downtown through air flows of the mountains and the rivers during wintertime and remained in the valley and became a cause of the cumulative air pollution. By 2018, more than 220,000 households are living in the ger area in Ulaanbaatar [5].

According to the ICD-X, all types of asthma coded as J45.0-Predominantly allergic asthma; J45.1-Non-allergic asthma; J45.8-Mixed Asthma and J45.9 J46.0-Unspecified asthma were used for data collecting.

In Ulaanbaatar 15 air quality monitoring stations are measure air pollutant including PM $2.5 \mu \mathrm{g} / \mathrm{m}^{3}, \mathrm{PM} 10 \mathrm{mg} / \mathrm{m}^{3}, \mathrm{SO}_{2} \mathrm{mg} / \mathrm{m}^{3}, \mathrm{NO}_{2} \mathrm{mg} / \mathrm{m}^{3}, \mathrm{CO} \mathrm{mg} / \mathrm{m}^{3}, \mathrm{O}_{3}$ $\mu \mathrm{g} / \mathrm{m}^{3}$. As well from the meteorological factors were used max, min and average temperature, humidity and wind speed. We get data from all stations which measure those indicators. Health and air pollution data will be collected in a routine based on related agencies. In Ulaanbaatar, 15 air quality monitoring stations are operating and out of the 12 had an automatic operating system. Thus, we used those 12 station's data for analyses of this article. All stations monitoring above mentioned indicators' were measured every 15 - 20 minutes daily. There are located in multisite places over the Ulaanbaatar city based on mobile and static pollutant's sources. The calibration of equipment is squared in accordance with the national standard MNS-17025.

\subsection{Data Analysis}

Data were analyzed by using the program STATA-12. For testing the differences of the results were used appropriate non-parametric tests were used the Kruskal-Wallis one-way analysis of variance and Mann-Whitney $U$ test as well. Furthermore, time-series cross-over and correlation analyses will be used for evaluating the health effects of air pollutants.

Furthermore, Spearman correlation analyses were used for evaluating the asthma hospital admission effect of air pollutants and meteorological parameters. Kolmogorov-Smirnoff test has been used to check the normality distribution of data.

To evaluate the lag effect in detail, we computed 24-h means starting from various times: the 0-h lag starts from 00:00 hours on a corresponding day, the 6-h lag starts from 18:00 hours on the previous day, and the 12-h lag starts from 12:00 hours on the previous day, ..., etc., and they last for $24 \mathrm{~h}$. The 6-, 12-, 18-, 72-h, 96-h lags were calculated and used to get the estimated effects. The 0-h lag 
is the pollutant value on the same day, the $24-\mathrm{h}$ lag is the 1-day lag value, the 48-h lag is the 2-day lag value, etc. In order to allow for different lag structures for different causes of disease, the traditional method, and the Gausson regression analysis were supplied for model comparison. We compared the three time-series models for lags of $0,1,2$ and 3 days.

Based on exposure-response functions from Ulaanbaatar and from the literature health impacts are derived using the equation below.

$$
E=((R R-1) / R R) * f_{p} * P O P
$$

where $E$ is the number of cases of each health endpoint attributed to air pollution ("excess cases"), $R R$ is the relative risk of asthma admission between two levels of pollution (here the current level and a lower level obtained from an intervention or the lower threshold level), this is the current incidence rate of the asthma hospital admission, and $P O P$ is the exposed population considered. In the following, we assume $P O P$ is the total population in Ulaanbaatar, which was 1.5 million in 2017. For asthma hospital admissions, we replace $f_{\mathrm{p}}{ }^{*} P O P$ with the actual annual number of hospital admissions.

$R R$ is given by:

$$
R R=\exp \left(\beta *\left(C-C_{t}\right)\right)
$$

where $\beta$ is the exposure-response coefficient, $C$ is the current pollution level and $\mathrm{Ct}$ is the target pollution level obtained from an intervention or the assumed threshold value.

\section{Results}

\subsection{The Air Quality of Ulaanbaatar}

The mean level of $\mathrm{SO}_{2}$ during the cold season was $35.22 \mu \mathrm{g} / \mathrm{m}^{3}$ [CI 95\%: 33.78 36.68 ] and during warm season it was $4.65 \mu \mathrm{g} / \mathrm{m}^{3}$ [CI 95\%: $4.43-4.86$ which is 7.57 times higher than the warm season. If compared to those levels with national standard and WHO recommended level, 1.8 times high during the cold period of time and 4.3 times less during the warm season (Figure 1(a), Table 1).

According to the $\mathrm{NO}_{2}$ level, the daily mean was $45.39 \mu \mathrm{g} / \mathrm{m}^{3}$ [CI 95\%: 44.56 46.19]. During the holiday ( $45.85 \mu \mathrm{g} / \mathrm{m}^{3}$ [CI 95\%: 44.92 - 46.83]) mean concentration of $\mathrm{NO}_{2}$ was significantly higher than the ordinary day mean concentration (44.34 $\mu \mathrm{g} / \mathrm{m}^{3}$ [CI 95\%: 42.93 - 45.73]). During the cold period $\left(52.95 \mu \mathrm{g} / \mathrm{m}^{3}\right.$ [CI 95\%: 51.96 - 53.99]) the mean concentration of $\mathrm{NO}_{2}$ was 1.66 times higher than the warm season (31.25 $\mu \mathrm{g} / \mathrm{m}^{3}$ [CI 95\%: 30.60 - 31.89) (Figure 1(b), Table 1).

The 24 hours average PM 2.5 concentration of cold season was $114.10 \mu \mathrm{g} / \mathrm{m}^{3}$ [CI 95\%: 109.16 - 119.04]. Regarding the 24 hours PM 10 concentration, during cold season daily average concentration was $226.77 \mu \mathrm{g} / \mathrm{m}^{3}$ [CI 95\%: 218.30 - 235.25]. The 24 hours average PM 2.5 concentration of cold season was higher than the warm season 3.9 times (Figure 1(c), Figure 1(d), Table 1). 

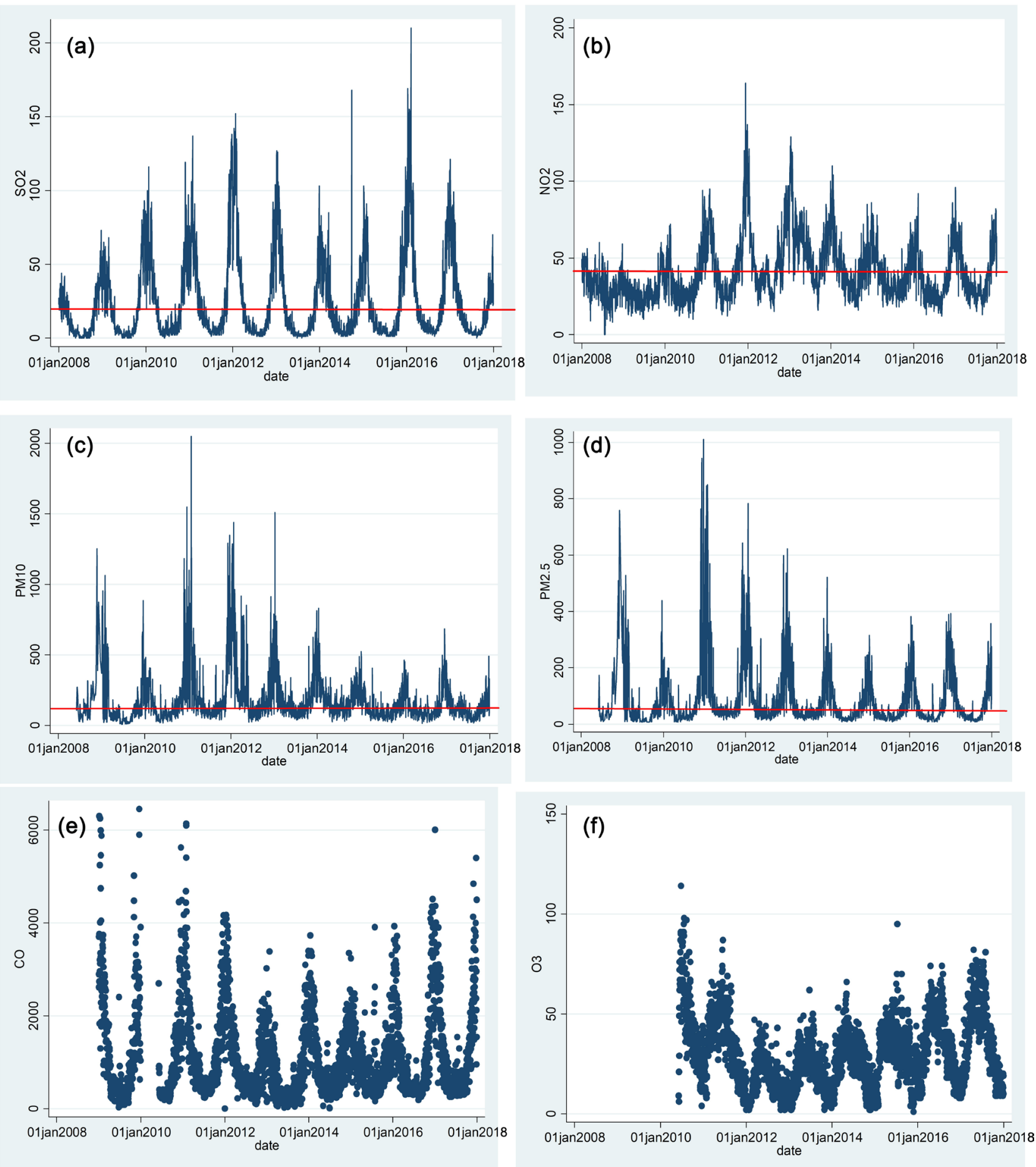

${ }^{*}$ Red line shows national standard level of the pollutants

Figure 1. 24 and 8 hours average daily concentration of $\mathrm{NO}_{2}, \mathrm{SO}_{2}, \mathrm{PM} 10, \mathrm{PM} 2.5$ (2008-2017), CO, and $\mathrm{O}_{3}$ (2010-2017) concentration, 2008-2017, Ulaanbaatar. (a) $\mathrm{SO}_{2}$ concentration; (b) $\mathrm{NO}_{2}$ concentration; (c) PM 10 concentration; (d) PM 2.5 concentration; (e) $\mathrm{CO}$ concentration; (f) $\mathrm{O}_{3}$ concentration.

Monitoring of carbon monoxide (since January 2010) and ozone (since January 2012) are not exceeded national standard permissible and WHO recommended level. The 8 hours average daily carbon monoxide concentration $\left(1352.85 \mu \mathrm{g} / \mathrm{m}^{3}\right.$ 
[CI 95\%: 1313.07 - 1396.15]) was high during the cold season, ground-level Ozone concentration (39.10 $\mu \mathrm{g} / \mathrm{m}^{3}$ [CI 95\%: 37.95 - 40.35]) was high during the warm season (Figure 1(e), Figure 1(f), Table 1).

Daily mean temperatures ranged from $-7.21^{\circ} \mathrm{C}$ to $16.40^{\circ} \mathrm{C}$. The mean wind velocity was $2.59 \mathrm{~m} / \mathrm{s}$ [95\% CI: $2.53-2.66$ ] during the warm season and $1.89 \mathrm{~m} / \mathrm{s}$ [95\% CI: 1.84 - 1.94] during the cold season. For the whole year, average temperature was $1.02^{\circ} \mathrm{C}$ [95\% CI: $0.46-1.60$ ], wind velocity was $2.14 \mathrm{~m} / \mathrm{s} 95 \% \mathrm{CI}$ : [2.09 - 2.18], relative humidity was $56.14 \%$ [ $95 \%$ CI: $55.54-56.75]$. The relative humidity was varied from cold to warm-season $51.74 \%$ [95\% CI: 50.65 - 52.88] to $51.48 \%$ [ $95 \%$ CI: 57.79 - 59.23] respectively (Table 1).

Table 1 shows the daily mean level of air pollutants, some meteorological factors and asthma hospital admission by different seasons and dows of the day.

\subsection{Air Pollution Short Term Impact on Asthma Hospital Admission}

There are 8283 asthma cases were recorded during study years in Ulaanbaatar. $68.2 \%$ of them were women, $80.0 \%$ of them were aged over 40 years old and $54.9 \%$ of them were registered during the winter and spring period of time. In one day 3.85 [95\% CI: 3.70 - 4.00] people admitted due to asthma (Table 1). The admission cases of asthma were registered during a cold period of time was 2.6

Table 1. Some meteorological and air pollutant's daily mean level, Ulaanbaatar.

\begin{tabular}{|c|c|c|c|c|c|}
\hline Indicators & $\begin{array}{l}\text { Ordinary day } \\
\text { Mean, } 95 \% \text { CI }\end{array}$ & $\begin{array}{c}\text { Holiday } \\
\text { Mean, 95\% CI }\end{array}$ & $\begin{array}{l}\text { Cold season } \\
\text { Mean, } 95 \% \text { CI }\end{array}$ & $\begin{array}{l}\text { Warm season } \\
\text { Mean, } 95 \% \text { CI }\end{array}$ & $\begin{array}{c}\text { Whole year } \\
\text { Mean, 95\% CI }\end{array}$ \\
\hline \multicolumn{6}{|l|}{ Air pollutants } \\
\hline $\mathrm{SO}_{2}, \mathrm{mg} / \mathrm{m}^{3}$ & 24.55 [23.27 - 25.89] & $24.56[22.60-26.70]$ & $35.22[33.78-36.68]$ & $4.65[4.43-4.86]$ & $24.56[23.42-25.68]$ \\
\hline $\mathrm{NO}_{2}, \mathrm{mg} / \mathrm{m}^{3}$ & $45.85[44.92-46.83]$ & $44.34[42.93-45.73]$ & $52.95[51.96-53.99]$ & $31.25[30.60-31.89]$ & $45.39[44.56-46.19]$ \\
\hline $\mathrm{PM} 2.5 \mu \mathrm{g} / \mathrm{m}^{3}$ & 85.29 [81.29 - 90.02] & 85.65 [79.59 - 92.17] & 114.10 [109.16 - 119.04] & $29.21[28.01-30.40]$ & $85.72[82.14-89.31]$ \\
\hline $\mathrm{CO} \mathrm{mg} / \mathrm{m}^{3}$ & $1058.42[1020.39-1101.08]$ & $1004.99[948.13-1066.72]$ & $\begin{array}{c}1352.85 \\
{[1313.07-1396.15]}\end{array}$ & $\begin{array}{c}461.34 \\
{[444.07-482.81]}\end{array}$ & $\begin{array}{c}1041.96 \\
{[1010.88-1076.00]}\end{array}$ \\
\hline $\mathrm{O}_{3} \mu \mathrm{g} / \mathrm{m}^{3}$ & $29.01[28.23-29.86]$ & $30.33[29.00-31.66]$ & $24.23[23.54-24.96]$ & $39.10[37.95-40.35]$ & $29.42[28.78-30.12]$ \\
\hline Ave tem & $1.17[0.48-1.84]$ & $0.70[-0.40-1.78]$ & $-7.21[-7.77--6.64]$ & $16.40[16.07-16.73]$ & $1.02[0.46-1.60]$ \\
\hline Min tem & $7.75[7.02-8.45]$ & $7.15[5.97-8.23]$ & $-0.82[-1.44--0.19]$ & $23.22[22.86-23.59]$ & $7.56[6.95-8.16]$ \\
\hline Max tem & $-4.33[-5.00--3.67]$ & $-4.67[-5.71--3.63]$ & $-12.39[-12.91--11.85]$ & $10.43[10.11-10.76]$ & $-4.43[-4.97--3.87]$ \\
\hline Wind velocity & $2.14[2.09-2.19]$ & $2.12[2.04-2.19]$ & $1.89[1.84-1.94]$ & $2.59[2.53-2.66]$ & $2.14[2.09-2.18]$ \\
\hline Humidity & $56.01[55.31-56.76]$ & $56.44[55.34-57.62]$ & $58.49[57.79-59.23]$ & $51.74[50.65-52.88]$ & $56.14[55.54-56.75]$ \\
\hline \multicolumn{6}{|l|}{ Asthma cases } \\
\hline $\begin{array}{c}\text { Daily No. of } \\
\text { asthma admission }\end{array}$ & $5.06[4.86-5.25]$ & $1.16[1.07-1.26]$ & $4.14[4.00-4.38]$ & $3.17[2.94-3.40]$ & $3.85[3.70-4.00]$ \\
\hline $\begin{array}{c}\text { Age of admitted } \\
\text { cases }\end{array}$ & $50.69[46.17-55.21]$ & $48.25[39.57-56.92]$ & 51.48 [51.09 - 21.87] & $50.08[49.39-5075]$ & $51.10[50.76-51.44]$ \\
\hline
\end{tabular}


times higher than the warmer time $(\mathrm{T}=19.46, \mathrm{p}<0.0001)$. Also during the weekdays' admission cases of asthma were registered 4.6 times higher than the holidays ( $\mathrm{T}=22.76, \mathrm{p}<0.0001)$. Mean age of asthma patient were 51.10 [50.7651.44] and was not observed significant difference in seasonal and daily difference on age (Table 2).

All correlation except ground-level ozone and asthma admission during the whole year was statistically significant. The general tendency of the whole year, all air pollutants apart from ground-level ozone had defined direct weak correlated with asthma hospital admission. The ground-level ozone had reversely correlated but it was not statistically significant with asthma admission. During the cold season, ambient air $\mathrm{SO}_{2}, \mathrm{mg} / \mathrm{m}^{3}, \mathrm{PM} 2.5 \mu \mathrm{g} / \mathrm{m}^{3}$, and $\mathrm{CO}, \mathrm{mg} / \mathrm{m}^{3}$ concentrations were directly weak correlated with asthma hospital admission. While, during warmer time ambient air PM $2.5 \mu \mathrm{g} / \mathrm{m}^{3}$, and $\mathrm{O}_{3}, \mu \mathrm{g} / \mathrm{m}^{3}$ concentrations were directly weak correlated with the asthma hospital admission.

Table 2. Asthma admission cases age classification, seasonal characteristics by its gender, Ulaanbaatar.

\begin{tabular}{|c|c|c|c|}
\hline \multirow{2}{*}{ Classification } & \multicolumn{2}{|c|}{ Gender } & \multirow{2}{*}{ Total, n, \% } \\
\hline & Male, n, \% & Female, n, \% & \\
\hline \multicolumn{4}{|l|}{ Age group } \\
\hline 0 & $4,0.2 \%$ & $0,0.0 \%$ & $4,0.0 \%$ \\
\hline $1-4$ & $33,1.3 \%$ & $34,0.6 \%$ & $67,0.8 \%$ \\
\hline $5-9$ & $75,2.8 \%$ & $47,0.8 \%$ & $122,1.5 \%$ \\
\hline $10-14$ & $77,2.9 \%$ & $42,0.7 \%$ & $119,1.4 \%$ \\
\hline $15-19$ & $45,1.7 \%$ & $52,0.9 \%$ & $97,1.2 \%$ \\
\hline $20-24$ & $62,2.4 \%$ & $95,1.7 \%$ & $157,1.9 \%$ \\
\hline $25-29$ & $85,3.2 \%$ & $167,3.0 \%$ & $252,3.0 \%$ \\
\hline $30-34$ & $114,4.3 \%$ & $245,4.3 \%$ & $359,4.3 \%$ \\
\hline $35-39$ & $132,5.0 \%$ & $356,6.3 \%$ & $488,5.9 \%$ \\
\hline $40-44$ & $186,7.1 \%$ & $493,8.7 \%$ & $679,8.2 \%$ \\
\hline $45-49$ & $287,10.9 \%$ & $818,14.5 \%$ & $1105,13.3 \%$ \\
\hline $50-54$ & $398,15.1 \%$ & $946,16.7 \%$ & $1344,16.2 \%$ \\
\hline $55-59$ & $321,12.2 \%$ & $695,12.3 \%$ & $1016,12.3 \%$ \\
\hline $60-64$ & $247,9.4 \%$ & $598,10.6 \%$ & $845,10.2 \%$ \\
\hline $70-74$ & $236,9.0 \%$ & $368,6.5 \%$ & $604,7.3 \%$ \\
\hline $75-79$ & $171,6.5 \%$ & $340,6.0 \%$ & $511,6.2 \%$ \\
\hline $80-84$ & $91,3.5 \%$ & $197,3.5 \%$ & $288,3.5 \%$ \\
\hline $85+$ & $68,2.6 \%$ & $158,2.8 \%$ & $226,2.7 \%$ \\
\hline \multicolumn{4}{|c|}{ Season, $\chi^{2}=11.23, \mathrm{p}=0.011$} \\
\hline Summer & $546,20.70 \%$ & $1004,17.80 \%$ & $1550,18.70 \%$ \\
\hline Autumn & $685,26.00 \%$ & $1502,26.60 \%$ & $2187,26.40 \%$ \\
\hline Winter & $736,28.00 \%$ & $1664,29.40 \%$ & $2400,29.00 \%$ \\
\hline Spring & $665,25.30 \%$ & $1481,26.20 \%$ & $2146,25.90 \%$ \\
\hline Total & $2632,31.8 \%$ & $5651,68.2 \%$ & $8283,100 \%$ \\
\hline
\end{tabular}


In general, an influence on the asthma admission of meteoroidal factors is reversely correlated. Only relative humidity has directly correlated with asthma. During the cold and warmer season, strong wind decreasing asthma admission. When during warmer season humidity is directly correlated with asthma admission. But all of the correlations were weak (Table 3).

Significant associations were found for $\mathrm{SO}_{2}$ in all lags. For $\mathrm{NO}_{2}$ was less associated with asthma only the first day it has a significant association. For PM 10 it was significant only Lag 0 and Lag 3, for PM 2.5 all lags except Lag 1, for CO also in all lags except lag 2. According to the $\mathrm{O}_{3}$, the first 2 Lags were observed in significant relation.

Every $10 \mathrm{mg} / \mathrm{m}^{3}$ increase in $\mathrm{SO}_{2}$ was associated with $0.9 \%$ [95\% CI: 0.3\% - 1.7\%; $\mathrm{p}=0.008$ ] and 1.7\% [95\% CI: $1.0 \%-2.4 \% ; \mathrm{p}<0.0001$ ] increase in estimated risk of asthma admission. For the $\mathrm{NO}_{2}$, every $10 \mu \mathrm{g} / \mathrm{m}^{3}$ increase was associated with $2.3 \%$ [95\% CI: 0.7\% - 3.8\%; $\mathrm{p}=0.004]$ increase in estimated risk of asthma admission.

According to the PM 10 and PM 2.5, every $10 \mu \mathrm{g} / \mathrm{m}^{3}$ increase in of their concentration in ambient air associated with 3.6\% [95\% CI: 2.9\% - 10.0\%; p < 0.0001 ] to $6.1 \%$ [95\% CI: $6.0 \%-16.0 \%$; p < 0.0001] and 3.1\% [95\% CI: $0.4 \%$ $5.8 \% ; \mathrm{p}=0.024$ ] to $4.4 \%$ [95\% CI: $2.0 \%-6.8 \%$; $\mathrm{p}<0.0001$ ] increase in estimated risk of asthma admission respectively.

Table 3. Matric of Spearman's correlation coefficient $(r)$ between mean daily concentration of pollutants and asthma admission cases, by Ulaanbaatar.

\begin{tabular}{|c|c|c|c|}
\hline & $\begin{array}{l}\text { Asthma }(\mathrm{J} 45 \text { - J46) } \\
\text { cold season }\end{array}$ & $\begin{array}{c}\text { Asthma }(\mathrm{J} 45 \text { - J46) } \\
\text { warm season }\end{array}$ & $\begin{array}{c}\text { Asthma }(\mathrm{J} 45-\mathrm{J} 46) \\
\text { whole year }\end{array}$ \\
\hline \multicolumn{4}{|l|}{ Air pollutants } \\
\hline $\mathrm{SO}_{2}, \mathrm{mg} / \mathrm{m}^{3}$ & $0.052^{*}$ & 0.034 & $0.123^{* *}$ \\
\hline $\mathrm{NO}_{2}, \mathrm{mg} / \mathrm{m}^{3}$ & -0.032 & -0.050 & $0.059^{* *}$ \\
\hline PM $10 \mu \mathrm{g} / \mathrm{m}^{3}$ & -0.037 & 0.020 & $0.054^{\star *}$ \\
\hline PM $2.5 \mu \mathrm{g} / \mathrm{m}^{3}$ & $0.080^{* *}$ & $0.108^{\star *}$ & $0.067^{\star *}$ \\
\hline $\mathrm{CO}, \mathrm{mg} / \mathrm{m}^{3}$ & $0.088^{\star *}$ & 0.021 & $0.117^{* *}$ \\
\hline $\mathrm{O}_{3}, \mu \mathrm{g} / \mathrm{m}^{3}$ & 0.002 & $0.071^{*}$ & -0.034 \\
\hline \multicolumn{4}{|l|}{ Meteorological factors } \\
\hline Average temperature & -0.009 & -0.030 & $-0.097^{\star *}$ \\
\hline Wind velocity & $-0.077^{\star \star}$ & $-0.115^{\star *}$ & $-0.120^{\star *}$ \\
\hline Wind max velocity & -0.024 & -0.035 & $-0.072^{* *}$ \\
\hline Min temperature & -0.010 & -0.047 & $-0.099^{* *}$ \\
\hline Max temperature & -0.009 & -0.007 & $-0.095^{\star *}$ \\
\hline Humidity & 0.010 & $0.059^{*}$ & $0.056^{* *}$ \\
\hline
\end{tabular}


Every $10 \mu \mathrm{g} / \mathrm{m}^{3}$ increase in ozone was associated with $2.3 \%$ [95\% CI: $0.7 \%$ 3.9\%; $\mathrm{p}<0.0001$ ] and 3.2\% [95\% CI: $1.5-5.1 ; \mathrm{p}<0.0001]$ increase in estimated risk of asthma admission.

While every $10 \mathrm{mg} / \mathrm{m}^{3}$ increase in CO was associated with $2.5 \%$ [95\% CI: $0.4 \%$ - 7.0\%; p.0.005] and 3.2\% [95\% CI: 1.5 - 5.1; p < 0.0001] increase in estimated risk of asthma admission (Table 4 ).

Table 4. Summary of hospital admission of asthma in relative risk (RR) and $95 \%$ confidence interval for $10 \mu \mathrm{g} / \mathrm{m}^{3}\left(\mathrm{mg} / \mathrm{m}^{3}\right)$ change in concentration of pollutants at mean lag 0 3 , significance with temperature and wind velocity adjusted by season.

\begin{tabular}{|c|c|c|c|}
\hline \multirow[t]{2}{*}{ Air pollutants } & \multirow[t]{2}{*}{ Lags } & \multicolumn{2}{|c|}{ Asthma (J45 - J46) in all age } \\
\hline & & RR [95\% CI] & $p$ value \\
\hline \multirow{4}{*}{$\mathrm{SO}_{2}, \mathrm{mg} / \mathrm{m}^{3}$} & Lag 0 & $0.11[0.03-0.18]$ & 0.006 \\
\hline & Lag 1 & $0.11[0.04-0.18]$ & 0.003 \\
\hline & Lag 2 & $0.09[0.03-0.17]$ & 0.008 \\
\hline & Lag 3 & $0.17[0.10-0.24]$ & $<0.0001$ \\
\hline \multirow{4}{*}{$\mathrm{NO}_{2}, \mathrm{mg} / \mathrm{m}^{3}$} & Lag 0 & $0.23[0.07-0.38]$ & 0.004 \\
\hline & Lag 1 & NS & \\
\hline & Lag 2 & & \\
\hline & Lag 3 & & \\
\hline \multirow{4}{*}{$\mathrm{PM} 10 \mu \mathrm{g} / \mathrm{m}^{3}$} & Lag 0 & $1.36[0.29-2.01]$ & $<0.0001$ \\
\hline & Lag 1 & NS & \\
\hline & Lag 2 & & \\
\hline & Lag 3 & $0.61[0.06-1.16]$ & 0.03 \\
\hline \multirow{4}{*}{ PM $2.5 \mu \mathrm{g} / \mathrm{m}^{3}$} & Lag 0 & $0.31[0.04-0.58]$ & 0.024 \\
\hline & Lag 1 & NS & \\
\hline & Lag 2 & $0.34[0.10-0.58]$ & $<0.0001$ \\
\hline & Lag 3 & $0.44[0.20-0.68]$ & $<0.0001$ \\
\hline \multirow{4}{*}{$\mathrm{CO}, \mathrm{mg} / \mathrm{m}^{3}$} & Lag 0 & $16.25[11.22-21.29]$ & $<0.0001$ \\
\hline & Lag 1 & $17.35[12.42-22.29]$ & $<0.0001$ \\
\hline & Lag 2 & NS & \\
\hline & Lag 3 & $9.57[4.97-14.16]$ & $<0.0001$ \\
\hline \multirow{4}{*}{$\mathrm{O}_{3}, \mu \mathrm{g} / \mathrm{m}^{3}$} & Lag 0 & $-0.23[-0.039--0.07]$ & 0.005 \\
\hline & Lag 1 & $-0.32[-0.51--0.15]$ & $<0.0001$ \\
\hline & Lag 2 & NS & \\
\hline & Lag 3 & & \\
\hline
\end{tabular}




\section{Discussion}

The present study has investigated the association of ambient air quality indicators (PM $2.5 \mu \mathrm{g} / \mathrm{m}^{3}$, PM $10 \mathrm{mg} / \mathrm{m}^{3}, \mathrm{SO}_{2} \mathrm{mg} / \mathrm{m}^{3}, \mathrm{NO}_{2} \mathrm{mg} / \mathrm{m}^{3}, \mathrm{CO} \mathrm{mg} / \mathrm{m}^{3}, \mathrm{O}_{3} \mathrm{mg} / \mathrm{m}^{3}$ ) and meteorological parameters (minimum, maximum, average temperature, relative humidity, and wind velocity) with asthma hospital admissions in capital city of Mongolia Ulaanbaatar in 2009-2018.

Air quality indicators were obtained from air quality stations and hospital admissions of asthma cases were obtained from the all level hospitals of Ulaanbaatar.

\subsection{The Air Quality of Ulaanbaatar}

Nowadays, the anthropogenic impact on the atmosphere has been increasing with the enormous growth of the human population, the use of mineral resources, and the advanced technology and continues to be significant.

Poor air quality in Mongolian cities is mainly caused by coal combustion in ger areas, thermal power plants, and motor vehicle emissions. Mongolians are burning coal for heating and cooking purposes. Whereas, other countries such as tropical and subtropical countries burn only for cooking purposes at the household level. Besides major air pollutant sources related to human activities in urban areas, especially in Ulaanbaatar, ecological factors, seasonal characteristics, and socio-economic factors have influenced the increase of air pollution. This is similar to China and some other coal consuming countries. This is different from tropical countries like Malaysia, Thailand, and the Philippines, where their main sources come from the forest fire, dust, and combustion of fossil and other fuels by industries, households, and vehicles [6].

Many researchers noted that during the wintertime, inverse cyclone flows come to Mongolia from Central Asia, causing temperature inversion to form in the city's atmosphere. The meteorological agency concluded that the temperature inversion was 500 to 800 meters of depth and 5 to 170 units of intensity. Due to this temperature inversion, dispersion of air pollutants and substances is slowed down and the smog over the city becomes stagnant. The geographical location and meteorological condition are contributing to the temperature inversion during the winter months. Extreme air pollution episodes were reported for the Muese Valley, Belgium, in 1930; Donora, PA, and the Monongehela River Valley in 1948; and London in 1952. In each of these cases, a persistent (3 to 6 days) temperature inversion combined with significant industrial and, in the case of London, domestic pollutant emissions, resulted in high ground-level concentrations that caused acute illness and, in some cases, death among the exposed populations [7].

The Air quality daily data compiled by this study indicated that the ambient air pollution levels in Ulaanbaatar was still relatively low, whereby the mean daily concentration being $24.56 \mathrm{mg} / \mathrm{m}^{3}$ for $\mathrm{SO}_{2}, 45.39 \mathrm{mg} / \mathrm{m}^{3}$ for $\mathrm{NO}_{2}, 182.73$ $\mu \mathrm{g} / \mathrm{m}^{3}$ for PM 10, $82.72 \mu \mathrm{g} / \mathrm{m}^{3}$ for PM 2.5, $1041.96 \mathrm{mg} / \mathrm{m}^{3}$ for CO, $29.42 \mathrm{mg} / \mathrm{m}^{3}$ for $\mathrm{O}_{3}$ in Ulaanbaatar. However, during the peak burning time which is from mid-autumn to mid-spring concentrations of the pollutants increased greatly. 
In the 1980s, a few air pollution episodes related to long-range transport from the east occurred in Western Europe. In 1985, increases in mortality and hospital admissions in Germany and temporary lung function changes in the Netherlands were seen during one such episode [7]. Attention shifted to weather-driven, day-to-day variations in air pollution over long periods of time as determinants of day-to-day variations in mortality, hospital admissions, and other public health indicators [8]. Such time-series studies were sporadic until about 1990, (Ostro 1984 [9]; Schwartz \& Marcus 1990 [10]) but have increased exponentially since then.

According to this survey air pollution has been increasing intensively during the last decade in big cities of Mongolia especially in Ulaanbaatar due to urbanization, poor urban plan, migration from rural areas to urban areas, poverty, unemployment, economic crises, exercise with unclean technology mainly coal for heating and cooking, raise of number of motor vehicle and other air pollution sources; as result of this phenomena, population health has been worsening. The modest contribution of stationary sources is caused by the high concentration due to the emissions from large power plants, which have substantial stack heights, within the study area [11].

Traffic-related air pollution is currently a growing concern, and $\mathrm{NO}_{2}$ may serve as a surrogate for traffic-related combustion products [12]. In Ulaanbaatar, $\mathrm{NO}_{2}$ level, daily mean was $45.39 \mu \mathrm{g} / \mathrm{m}^{3}$ [CI 95\%: 44.56 - 46.19] which was $4.56 \mu \mathrm{g} / \mathrm{m}^{3}$ higher from the permissible level of national standard and WHO recommendation level. Also during the holiday $\left(45.85 \mu \mathrm{g} / \mathrm{m}^{3}\right.$ [CI 95\%: 44.92 - 46.83]) mean concentration of $\mathrm{NO}_{2}$ was significantly higher than the ordinary day mean concentration (44.34 $\mu \mathrm{g} / \mathrm{m}^{3}$ [CI 95\%: 42.93 - 45.73]). During the warm season, $0.2 \%$ of $\mathrm{SO}_{2}$ concentration and $12.0 \%$ of $\mathrm{NO}_{2}$ were exceeded from the permissible level. Whereas during cold season $58.8 \%$ of $\mathrm{SO}_{2}$ concentration and $55.0 \%$ of $\mathrm{NO}_{2}$ were exceeded from the permissible level.

The 24 hours average PM 2.5 concentration of cold season was $114.10 \mu \mathrm{g} / \mathrm{m}^{3}$ [CI 95\%: 109.16 - 119.04]. Regarding the 24 hours PM 10 concentration, during cold season daily average concentration was $226.77 \mu \mathrm{g} / \mathrm{m}^{3}$ [CI 95\%: 218.30 235.25]. The 24 hours average PM 2.5 concentration of cold season was higher than the warm season 3.9 times, 2.3 times higher than the national standard level and 8.6 times higher than the WHO recommended level. Whereas, 24 hours PM 10 concentration was 2.4 times higher than the warm season, 3.7 times higher than the national standard level and 9.1 times higher than the WHO recommended level.

Monitoring of carbon monoxide (since January 2010) and ozone (since January 2012) are relatively new indicators of air quality monitoring in Mongolia. Those two pollutants are not exceeded the national standard permissible and WHO recommended level. The 8 hours average daily carbon monoxide concentration (1352.85 $\mu \mathrm{g} / \mathrm{m}^{3}$ [CI 95\%: 1313.07 - 1396.15]) was high during the cold season, ground-level Ozone concentration $\left(39.10 \mu \mathrm{g} / \mathrm{m}^{3}\right.$ [CI 95\%: 37.95 - 40.35]) was high during the warm season. 


\subsection{Impact of Air Pollution and Meteoroidal Factors to the Asthma Admission}

Mongolian weather condition is very harsh. The causes of air pollution episodes depend on several factors including local and regional emissions, topography and meteorological parameters including wind speed, wind direction, temperature, and solar radiation. The relative importance of such factors obviously depends on the climatic region and the season of the year. Examples have been cited from London, Oslo, Helsinki, and Milan. For instance, for London, the frequency of low wind speeds $(<2 \mathrm{~m} / \mathrm{s})$ can be typically $25 \%$. Such conditions can lead to local episodes of air pollution [13].

In northern Europe, the lowest ambient temperature is in most cases encountered during meteorological situations with a stable atmospheric stratification. A stable atmospheric stratification with low wind speeds or calm conditions is most unfavorable in terms of air pollution. Regarding air pollution episodes of PM 10 and $\mathrm{NO}_{2}$, elevated atmospheric pressure is commonly necessary, but not a sufficient condition, for the occurrence of an episode [14].

The general tendency of the whole year, all air pollutants apart from ground-level ozone had defined direct weak correlated with asthma hospital admission. During the cold season, ambient air $\mathrm{SO}_{2}, \mathrm{mg} / \mathrm{m}^{3}, \mathrm{PM} 2.5 \mu \mathrm{g} / \mathrm{m}^{3}$, and $\mathrm{CO}, \mathrm{mg} / \mathrm{m}^{3}$ concentrations were directly weak correlated with asthma hospital admission. Low wind speed is statistically significantly related to stable atmospheric stratification. On the other hand, the re-suspension of particles from road and street surfaces increases with increasing wind speed. Hollander et al. (1999) [15] observed qualitatively the same dependency for particle number concentrations in the city of Kuopio in Finland the seasonal variations of air pollution indexes and the relevant statistical properties from autumn 1999 to summer 2003 were seen in Hong Kong. Such phenomena are mainly affected by the Hong Kong weather cycle with heavy rainfall and southeast wind dominant during the summer, dry and cool air and northwest wind dominant in winter [16].

Findings of the survey by Enkhjargal A. et al [17] shows the percentage of combined effects on respiratory diseases in the winter season is 52.9 for average temperature, humidity, nitrogen dioxide, and PM 10; the percentage of combined effects on cardiovascular diseases in the winter season is 37.2 for average temperature, humidity, nitrogen dioxide, and PM 10; the percentage in the autumn is 5.4 for PM 10 only, and the percentage in the summertime is 17.4 for wind speed and average temperature, while in the autumn the percentage of combined effects of sulfur dioxide, nitrogen dioxide, and PM 10 is 25.4.

Epidemiological data do not show any evidence of excess asthma mortality associated with $\mathrm{SO}_{2}$ exposure in urban areas. Exposure data indicate that peak $\mathrm{SO}_{2}$ concentrations greater than the $1.34 \mu \mathrm{g} / \mathrm{m}^{3}$ may cause mild to moderate asthmatic individuals residing in the vicinity of certain sources to be at increased risk [18].

Wong et al. (2002) [19] conclude that for respiratory admissions ( $\geq 65$ years of 
age), significant positive associations were observed PM 10, nitrogen dioxide, sulfur dioxide, and ozone in 2 cities. These associations tended to be stronger at shorter lags in Hong Kong and at longer lags in London. Associations were stronger in the cool season in Hong Kong and in the warm season in London, periods during which levels of humidity are at their lowest in each city. For cardiac admissions (all ages) in both cities, significant positive associations were observed

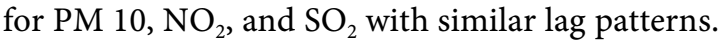

The association between increased emergency department visits for asthma and air pollution was investigated in Anchorage, Alaska [20], Reno, Nev [21], and Seattle, Wash [22]. All 3 studies found significant associations between various measures of PM 10 and increases in visits for asthma. In Seattle, a change of $11 \mu \mathrm{g} / \mathrm{m}^{3}$ in PM 2.5 was associated with a $15 \%$ increase in asthma visits. The Anchorage and Reno studies did not find a significant association between emergency department visits for asthma and carbon monoxide (CO); however, $\mathrm{CO}$ was associated with asthma visits in Seattle. In the Seattle study, there was a high correlation between 24-hour CO concentrations and PM 10 values (0.74). Other investigators have reported that the peak hourly $\mathrm{NO}_{2}$ concentration was significantly associated with increased emergency department visits for asthma during winter months in Northern California [23] and with increased emergency department visits and respiratory admissions in Athens, Greece [24]. Peak hourly $\mathrm{NO}_{2}$ was also associated with increased emergency department visits for asthma during both the winter and summer months in Barcelona, Spain [25].

In this study, every $10 \mathrm{mg} / \mathrm{m}^{3}$ increase in $\mathrm{SO}_{2}$ was associated with $0.9 \%-1.7 \%$, for the $\mathrm{NO}_{2}$, it was $2.3 \%$, for PM2.5 3.1\% - 4.4\%, for ozone $2.3 \%-3.2 \%$, and for $\mathrm{CO}$ it was $2.5 \%-3.2 \%$ increase of asthma admission.

In Ulaanbaatar, it has been estimated for PM 10 that every $10 \mathrm{mg} / \mathrm{m}^{3}$ increase of air pollutants $3.6 \%-6.1 \%$ in the estimated risk of asthma admission. The most health-hazardous pollutant in Mongolian is PM 10 level which shows its chemical source is different from other countries, mainly natural characteristics. It was similar to the above mentioned 3 cities (Anchorage, Reno, and Seattle).

The correlation mainly between asthma admissions cases with meteorological parameters is because the cold winter conditions in Ulaanbaatar result in the accumulation of pollutants in the atmosphere. Thus, population exposure to air pollution is increasing significantly during the winter months.

In conclusion, in recent years, air pollution is increasing sharply in Mongolia. The main cause of poor air quality is coal combustion in the ger areas, thermal power plants, and motor vehicles. The associations between air pollution and asthma hospital admission have been well established by many researchers throughout the world ever since the fateful incident of the London Fog of 1952. Thus, as expected this study demonstrated significant correlations between asthma hospital admission with PM 2.5, PM 10, $\mathrm{SO}_{2}, \mathrm{NO}_{2}, \mathrm{CO}, \mathrm{O}_{3}$, and some meteorological parameters. The correlation mainly between asthma admission cases with meteorological parameters is because of the cold winter condition. 
Thus population exposure to air pollution increases significantly in the winter months.

Our study has several limitations. We estimated only hospital admission data instead of including emergency room visits and outpatient asthma data.

\section{Acknowledgements}

Special thanks to the UNICEF country office in Mongolia for financial support for conducting the survey and all data collectors for their excellent cooperative work.

\section{Conflicts of Interest}

The authors declare no conflicts of interest regarding the publication of this paper.

\section{References}

[1] Global Initiative for Asthma (2016) Global Strategy for Asthma Management and Prevention. http://www.ginasthma.org

[2] Zheng, X.-Y., Ding, H., Jiang, L.-N., Chen, S.-W., Zheng, J.-P., Qiu, M., Zhou, Y., Chen, Q. and Guan, W. (2015) Association between Air Pollutants and Asthma Emergency Room Visits and Hospital Admissions in Time Series Studies: A Systematic Review and Meta-Analysis. PLoS ONE, 10, e0138146.

https://doi.org/10.1371/journal.pone.0138146

[3] NSO (2013) 5th MDG Progress Report, Ulaanbaatar, Mongolia.

[4] Government of Mongolia, NAC, UNICEF (2014) Chapter 5. Planning for the Future: Safe Water and Environmental Sanitation Analysis of the Situation of Children in Mongolia, Ulaanbaatar. 40.

[5] NSO (2019) Air Pollution and Health. UB Statistics Department, Ulaanbaatar.

[6] Haas, T.C. (1995) Local Prediction of a Spatio-Temporal Process with an Application to Wet Sulfate Deposition. Journal of the American Statistical Association, 90, 1189-1199. https://doi.org/10.1080/01621459.1995.10476625

[7] Godish, T. (2004) Air Quality. 4th Edition, Lewis Publishers, Boca Raton.

[8] Brunekreef, H.B. and Holgate, S.T. (2002) Air Pollution and Health. The Lancet, 360, 1233-1242. https://doi.org/10.1016/S0140-6736(02)11274-8

[9] Ostro, B. (1984) A Search for a Threshold in the Relationship of Air Pollution to Mortality: A Reanalysis of Data on London Winters. Environmental Health Perspectives, 58, 397-399. https://doi.org/10.1289/ehp.8458397

[10] Schwartz, J. and Marcus, A. (1990) Mortality and Air Pollution in London: A Time Series Analysis. American Journal of Epidemiology, 131, 185-194. https://doi.org/10.1093/oxfordjournals.aje.a115473

[11] Hussein, T., Karppinen, A., Kukkonen, J., Harko, J., Aalto, P.P., Ha, K., Kerminen, V.-M. and Kulmala, M. (2005) Meteorological Dependence of Size-Fractionated Number Concentrations of Urban Aerosol Particles. Atmospheric Environment, 40, 1427-1440. https://doi.org/10.1016/j.atmosenv.2005.10.061

[12] Schwartz, J. (1994) Air Pollution and Daily Mortality: A Review and Meta-Analysis. Environmental Research, 64, 36-52. https://doi.org/10.1006/enrs.1994.1005 
[13] Sokhi, R.S., Luhana, L., Kukkonen, J., Berge, E., Slördal, L.H. and Finardi, S. (2002) Analysis and Evaluation of Air Pollution Episodes in European Cities. In: Piringer, M. and Kukkonen, J., Eds., Proceedings of the COST 715 Expert Meeting "Mixing Height and Inversions in Urban Areas", Toulouse, 3-4 October 2001, 65-74.

[14] Pohjola, M.A., Rantamäki, M., Kukkonen, J., Karppinen, A. and Berge, E. (2004) Meteorological Evaluation of a Severe Air Pollution Episode in Helsinki on 27-29 December 1995. Boreal Environment Research, 9, 75-87.

[15] Hollander, A.E., Melse, J.M., Lebret, E. and Kramers, P.G. (1999) An Aggregate Public Health Indicator to Represent the Impact of Multiple Environmental Exposures. Epidemiology, 10, 606-617. https://doi.org/10.1097/00001648-199909000-00030

[16] Wang, X. and Lu, W. (2005) Seasonal Variation of Air Pollution Index: Hong Kong Case Study. Chemosphere, 63, 1261-1272. https://doi.org/10.1016/j.chemosphere.2005.10.031

[17] Altangerel, E., Burmaajav, B. and Batbaatar, S. (2014) Health Impact Assessment of Ambient Air PM10 and PM2.5 on Acute and Chronic RSD and CVD in Ulaanbaatar City. Health Sciences, 11, 49-53.

[18] WHO (1997) Health and Environment in Sustainable Development. Geneva.

[19] Wong, C.-M., Atkinson, R.W., Anderson, H.R., Hedley, A.J., Ma, S., Chau, P.Y.-K. and Lam, T.-H. (2002) A Tale of Two Cities: Effects of Air Pollution on Hospital Admissions in Hong Kong and London Compared. Environmental Health Perspectives, 110, 67-77. https://doi.org/10.1289/ehp.0211067

[20] Gordian, M.E., Ozkaynak, H., Xue, J., Morris, S.S. and Spengler, J.D. (1996) Particulate Air Pollution and Respiratory Disease in Anchorage, Alaska. Environmental Health Perspectives, 104, 290-297. https://doi.org/10.1289/ehp.96104290

[21] Yang, W., Jennison, B.L. and Omaye, S.T. (1997) Air Pollution and Asthma Emergency Room Visits in Reno, Nevada. Inhalation Toxicology, 9, 15-29. https://doi.org/10.1080/089583797198385

[22] Orris, G., YoungPong, S.N., Koenig, J.Q., Larson, T.V., Sheppard, L. and Stout, J.W. (1999) An Association between Fine Particles and Asthma Emergency Department Visit for Children in Seattle. Environmental Health Perspectives, 107, 489-493. https://doi.org/10.1289/ehp.99107489

[23] Lipsett, M., Hurley, S.B. and Ostro, B. (1997) Air Pollution and Emergency Room Visits for Asthma in Santa Clara County, California. Environmental Health Perspectives, 105, 216-222. https://doi.org/10.1289/ehp.97105216

[24] Pantazopoulou, A., Katsouyanni, K., Kourea-Kremastinou, J. and Trichopoulos, D. (1995) Short-Term Effects of Air Pollution on Hospital Emergency Outpatient Visits and Admissions in the Greater Athens, and Greece Area. Environmental Research, 69, 31-36. https://doi.org/10.1006/enrs.1995.1022

[25] Castellsague, J., Sunyer, J., Saez, M. and Anto, J.M. (1995) Short-Term Association between Air Pollution and Emergency Room Visits for Asthma in Barcelona. Thorax, 50, 1051-1056. https://doi.org/10.1136/thx.50.10.1051 